\title{
IMPROVING IPA STUDENTS' ACHIEVEMENT IN GREEN GROWTH MATERIALS AT THE FIFTH GRADE STUDENTS THROUGH COOPERATIVE LEARNING METHOD TYPE STAD IN SDN 06 PERAWANG BARAT 2013/ 2014
}

\author{
ARIANIS \\ Volume 1 Nomor 1 \\ JIPS ISSN: 2579-5449
}

\begin{abstract}
Teachers make various efforts to improve student learning outcomes. Therefore, it is needed a learning action that can enliven the students' motivation in achieving good values, individually or in groups. One way is to implement cooperative learning. In this learning students are required to work together in small groups to solve a problem and the group's primary goal is toward success. STAD type cooperative learning is based on an idea where students work together in a group and participate personally in the learning activities of their group members. Based on the background of the problems can be formulated as follows: "if the implementation of cooperative learning model STAD can improve learning outcomes of students in class V SDN 06 IPA in Perawang

The purpose of this research is to improve learning outcomes IPA fifth grade students of SDN 06 Perawang Barat on green plant material. The research method was classroom action research. This research was conducted at SDN 06 Perawang Barat. The research time is from February to May 2014.

The subjects were students of class V SDN 06 Perawang Barat in academic year 2013/2014, amounting to 32 students consisting of 14 male male and 18 female students. Instruments of the research are consisting of syllabus, assessment system, lesson plan, and student work sheet.

Based on the results, it can be concluded that the implementation of cooperative learning model STAD able to improve learning outcomes IPA class V SDN 06 in Perawang Barat.
\end{abstract} Barat in green plant matter?"

Keywords: IPA students' achievement, green growth materials, cooperative learning Method STAD.

\section{UPAYA PENINGKATAN HASIL BELAJAR IPA SISWA MATERI TUMBUHAN HIJAU DI KELAS V MELALUI MODEL PEMBELAJARAN KOOPERATIF TIPE STAD SDN 06 PERAWANG BARAT 2013/2014}

\author{
ABSTRAK
}


Guru melakukan berbagai usaha untuk meningkatkan hasil belajar siswa. Oleh karena itu diperlukan satu tindakan pembelajaran yang dapat menghidupkan motivasi siswa dalam pencapaian nilai yang baik, secara individu maupun kelompok. Salah satu cara denngan menerapkan pembelajaran kelompok kooperatif. Dalam pembelajaran ini siswa dituntut untuk bekerja sama dalam kelompok kecil untuk memecahkan suatu masalah dan tujuan utama kelompok adalah menuju keberhasilan. Pembelajaran kooperatif tipe STAD berdasarkan pada suatu ide dimana siswa bekerja sama dalam suatu kelompok dan turut serta bertanggungjawab secara pribadi pada aktivitas belajar anggota kelompoknya. Berdasarkan latar belakang permasalahan dapat dirumuskan sebagai berikut: "apakah penerapan model pembelajaran kooperatif tipe STAD dapat meningkatkan hasil belajar ipa siswa dikelas $\mathrm{V}$
SDN 06 Perawang Barat pada materi tumbuhan hijau?"

Tujuan penelitian ini adalah untuk meningkatkan hasil belajar ipa siswa kelas V SDN 06 Perawang Barat pada materi tumbuhan hijau. Metode penelitian adalah penelitian tindakan kelas. Penelitian ini dilaksanakan di SDN 06 Perawang Barat. Waktu penelitian bulan Februari sampai Mei 2014.

Subjek penelitian ini adalah siswa siswi kelas V SDN 06 Perawang barat tahun ajaran 2013/2014 yang berjumlah 32 siswa yang terdiri dari 14 laki - laki dan 18 siswa perempuan. Instrumen Penelitian terdiri dari silabus, sitem penilaian, RPP, dan lembaran kerja siswa.

Berdasarkan hasil penelitian, dapat diambil kesimpulan, bahwa penerapan model pembelajaran kooperatif tipe STAD mampu meningkatkan hasil belajar ipa kelas V SDN 06 Perawang Barat.

\section{Keywords: hasil belajar IPA, materi tumbuhan hijau, kooperatif tipe STAD}

\section{PENDAHULUAN}

Latar belakang, Ilmu Pengetahuan Alam merupakan salah satu mata pelajaran yang dipelajari di tingkat sekolah dasar. Merupakan salah satu disiplin ilmu yang besar pengaruhnya terhadap perkembangan IPTEK. Secara umum tujuan mata pelajaran IPA adalah siswa memahami materi ipa dan mampu mengorganisasikan metode ilmiah yang dilandasi sikap ilmiah untuk memecahkan masalah yang dihadapinya, sehingga menyadari kekuasaan dan kebesaran penciptanya.

Pentingnya penguasaan ilmu pengetahuan alam memberi andil bagi pencapaian tujuan pendidikan secara umum, yaitu manusia mampu berfikir logis, sistematis, cermat, serta berfikir objektif dan terbuka dalam menghadapi permasalahan.

Ilmu Pengetahuan Alam memiliki struktur dan keterkaitan yang kuat dan jelas antara konsepnya. Dalam mencapai tujuan pembelajaran ipa tidak terlepas dari peranan guru dalam proses pembelajaran, baik metode maupun media yang digunakan. Guru harus mampu menciptakan proses pembelajaran yang tepat sehingga dapat melibatkan siswa secara optimal dalam proses belajar mengajar. Dengan demikian tujuan pembelajaran yang diterapkan dapat tercapai.

Berdasarkan data dan informasi dari guru pada tahun sebelumnya di kelas V. SDN 06 Perawang Barat bahwa hasil belajar yang diperoleh siswa kelas V SDN 06 Perawang Barat masih rendah. Dimana siswa yang belum mencapai KKM 55,6\%. Hal ini disebabkan oleh faktor internal yaitu kondisi fisik siswa, psikologi siswa yang meliputi kecerdasan, minat, bakat, motivasi dan kemampuan kognitif. Disamping itu juga disebabkan oleh rasa bosan dan malu saat berlangsungnya pembelajaran sehingga materi tidak sepenuhnya dimengerti. Sedangkan faktor eksternal siswa adalah keberadaan guru, dimana kurangnya motivasi 
dalam pembelajaran dan kurangnya kesempatan yang diberikan kepada siswa untuk menyampaikan hasil kerjanya karena dominasi guru.

Guru melakukan berbagai usaha untuk meningkatkan hasil belajar siswa. Oleh karena itu diperlukan satu tindakan pembelajaran yang dapat menghidupkan motivasi siswa dalam pencapaian nilai yang baik, secara individu maupun kelompok. Salah satu cara denngan menerapkan pembelajaran kelompok kooperatif. Dalam pembelajaran ini siswa dituntut untuk bekerja sama dalam kelompok kecil untuk memecahkan suatu masalah dan tujuan utama kelompok adalah menuju keberhasilan. Pembelajaran kooperatif tipe STAD berdasarkan pada suatu ide dimana siswa bekerja sama dalam suatu kelompok dan turut serta bertanggungjawab secara pribadi pada aktivitas belajar anggota kelompoknya.

SDN 06 Perawang Barat belum pernah menerapkan pembelajaran kooperatif tipe STAD sebagai salah satu cara meningkatkan hasil

\section{METODE PENELITIAN}

\section{A. Tempat dan Waktu Penelitian}

Penelitian ini dilaksanakan di SDN 06 Perawang Barat. Waktu penelitian bulan Februari sampai Mei 2014.

\section{B. Subjek Penelitian}

Subjek penelitian ini adalah siswa siswi kelas V SDN 06 Perawang barat tahun ajaran 2013/2014 yang berjumlah 32 siswa yang terdiri dari 14 laki - laki dan 18 siswa perempuan.

\section{Bentuk Penelitian}

Penelitian terdiri dari dua siklus, siklus I dilaksanakan terdiri dari 2 kali pertemuan, 2 buah RPP dan satu kali ulangan harian I. siklus II dilaksanakan untuk perbaikan siklus I, terdiri dari dua kali pertemuan dengan 2 buah RPP dan satu kali ulangan harian II. Jika belum berhasil dilanjutkan siklus berikutnya.

Siklus terdiri dari:

Penelitian dilakukan oleh peneliti sendiri bekerja sama dengan guru ipa. Berdasarkan permasalahan tentang rendahnya hasil belajar ipa pada materi ipa. Perencanaan pembelajaran dilakukan dengan menyusun RPP, mempersiapkan lembaran kerja siswa dan belajar siswa dalam pembelajaran IPA. Berdasarkan hal tersebut, maka penulis melakukan penelitian dengan judul "Upaya Meningkatkan Peningkatan Hasil Belajar IPA Siswa pada Materi Tumbuhan Hijau Dikelas V Melalui Model Pembelajaran Kooperatif Tipe STAD di SDN 06 Perawang Barat T.A 2013/2014.

Untuk dapat melaksanakan pembelajaran ipa dengan penerapan model pembelajaran tipe STAD maka diperlukan antara guru ipa dan peneliti melalui PTK.

Berdasarkan latar belakang permasalahan dapat dirumuskan sebagai berikut: "apakah penerapan model pembelajaran kooperatif tipe STAD dapat meningkatkan hasil belajar ipa siswa dikelas V SDN 06 Perawang Barat pada materi tumbuhan hijau?"

Tujuan penelitian ini adalah untuk meningkatkan hasil belajar ipa siswa kelas V SDN 06 Perawang Barat pada materi tumbuhan hijau.

merencanakan tes hasil belajar serta mempersiapkan lembar pengamatan. Kriteria yang diharapkan setelah diadakan tindakan terdapat perubahan aktivitas siswa dan guru terdapat hasil belajar $75 \%$ dengan $\mathrm{KKM} \geq 65$.

Langkah - langkah pembelajaran yang sudah direncanakan sebagai berikut: 1) Penerapan pembelajaran kooperatif tipe STAD untuk materi tumbuhan hijau dilibatkan secara aktif dalam kelompoknya. 2) Siswa yang belum mengerti diberi kesempatan bertanya kepada anggota kelompoknya yang pandai. 3) Siswa menegrjakan LKS sebagai latihan. 4) Guru bersama siswa menyimpulkan pelajaran. 4) Guru memberikan pekerjaan rumah.

Pengamatan dilaksanakan dengan menggunakan lembar pengamatan, dengan mengamati tindakan dalam proses pembelajaran menggunakan model pembelajaran kooperatif tipe STAD.

Hasil yang diperoleh pada tahap pengamatan dan evaluasi dilakukan analisis. Kelemahan - kelemahan yang terjadi pada setiap siklus akan diperbaiki pada siklus berikutnya. 


\section{Instrumen Penilaian}

Perangkat pembelajaran terdiri dari silabus, sitem penilaian, RPP, dan lembaran kerja siswa. 1) Silabus dan sistem penilaian

Silabus dan sistem penilaian ini disusun berdasarkan prinsip - prisnip pencapaian kompetensi, yang terdiri dari standar kompetensi, kompetensi dasar, materi pokok, kegiatan pembelajaran, indikator, penilaian yang meliputi jenis tagihan, bentuk instrument. 2) RPP disusun secara secara sitematis yang terdiri dari:standar kompetensi, kompetensi dasar, indikator, tujuan pembelajaran, materi pokok, model, metode pembelajaran, serta langkah - langkah pembelajaran yang memuat kegiatan awal, kegiatan inti, dan kegiatan akhir. 3) Lembaran kerja siswa merupakan latihan soal yang dikerjakan sebagai bentuk pelatihan soal - soal yang lebih komplek.

Teknik pengumpulan data yang digunakan ini dnegan menggunakan lembar pengamatan yang diisi oleh pengamat. Pengamat bertugas mengamati dan mencatat aktifitas guru dan siswa selama proses pembelajaran.

Sedangkan untuk pengumpulan data tentang hasil belajar siswa pada pelajaran ipa dengan mengadakan ulanagan harian.

Pengumpulan data selama proses pembelajaran pada setiap indikator. Dalam penelitian ini tes hasil belajar ipa dilakukan dengan ulangan harian I dan ulangan harian II.

Data yang diperoleh melalui hasil penelitian ini berupa aktiviti guru dan siswa selama proses pembelajaran berlangsung serta data hasil belajar berupa nilai ulangan harian I dan ulangan harian II. Data analisis sehingga diperoleh kesimpulan tentang hasil penelitian yang dilakukan.

Pelaksanaan pembelajaran dikatakan berhasil jika aktivitas guru dan siswa pada pembelajaran berlangsung sesuai dengan rencana pembelajaran. Aktivitas guru sebanyak 6 aktivitas, ssedangkan aktivitas siswa sebanyak 7 aktivitas. Menurut KTSP dalam Syahrilfuddin dkk (2011:81). Untuk menilai aktivitas guru dan siswa dihitung dengan rumus sebagai berikut:

$$
\mathrm{NR}=\frac{\not S}{S M} \times 100 \%
$$

NR : persentase rata - rata aktivitas (guru/siswa)

JS : jumlah skor aktivitas yang dilakukan

SM : skor maksimum yang didapat dari aktivitas guru/siswa

Nilai rata - rata aktivitas guru dan siswa tersebut kemudian dikategorikan dengan interval baku berdasarkan tabel berikut:

Tabel 3.1

Kategori Aktivitas Guru dan Siswa

\begin{tabular}{|c|c|}
\hline Persen interval & Kategori \\
\hline $81-100$ & Amat baik \\
$61-80$ & Baik \\
$51-60$ & Cukup \\
Kurang dari 50 & Kurang \\
\hline
\end{tabular}

Sumber: KTSP (2007:367) dalam Syahrilfuddin dkk (2011:82)

Kriteria Ketuntasan Minimal (KKM) mata pelajaran ipa yang ditetapkan SDN 06 Perawang Barat adalah $\geq 70$. Nilai hasil ulangan harian I dan II dilakukan ananlisis secara kuantitatif dengan beberapa tahapan pengolahan. Tahap pertama data untuk setiap ulangan harian diolah. Analisis data tentang hasil belajar siswa pada materi pokok tumbuhan hijau dapat dilihat dengan membandingkan skor dasar dengan skor ulangan harian I dan ulangan harian II.

Menurut Purwanto dalam Syahrilfuddin dkk (2011:82), untuk menentukan ketuntasan belajar siswa sevara individu dapat dihitung dengan menggunakan persamaan sebagai berikut:

$\mathrm{PK}=\frac{S P}{S M} \times 100 \%$

PK : persentase ketuntasan individu

SP : skor yang diperoleh siswa

SM : skor maksimum 
Menurut Mulyasa (2009:183) untuk menentukan ketuntasan klasikal apabila 75\% dari seluruh siswa dapat mencapai KKM. Adapun presentasi ketuntasan klasikal menurut Purwanto dalam Syahrifuddin dkk (2011:82) dihitung dengan menggunakan rumus sebagai berikut:

PK $=\frac{S T}{N} \times 100 \%$

PK : ketuntasan klasikal

ST : jumlah siswa yang tuntas

SM : jumlah seluruh siswa

Apabila jumlah siswa yang mencapai KKM setelah dilakukan tindakan lebih banyak dari jumlah siswa yang mencapai KKM sebelum tindakan dilakukan maka proses pembelajaran dikatakan berhasil.

Hasil pengamatan dibandingkan dengan karakteristik model pembelajaran kooperatif tipe STAD sehingga diperoleh gambaran kelemahan - kelemahan dan kendala yang dihadapi selama penelitian berlangsung.

Analisis Penghargaan Kelompok Tingkat penghargaan kelompok diambil dari tes yang diadakan setelah pemberian ulangan harian (UH 1). Skor individu setiap kelompok memberi sumbangan pada kelompok berdasarkan rentang skor yang diperoleh setelah tes akhir.

Untuk mengetahui berbagai tingkat penghargaan kelompok yang akan diberikan terhadap kelompok yang berprestasi, kriteria predikat nilai perkembangan kelompok.

\section{HASIL PENELITIAN DAN PEMBAHASAN}

Proses pelaksanaan pembelajaran dengan penerapan pembelajaran kooperatif tipe STAD terhadap siswa kelas V SDN 06 Perawang Barat. Penelitian ini melalui beberapa tahap sebagai berikut:

Tahap Persiapan, Pada tahap persiapan ini penelitian mempersiapkan instrument penelitian yang terdiri dari silabus, RPP, lembar tugas yang disusun untuk empat kali pertemuan dengan penerapan pembelajaran kooperatif tipe STAD pada materi tumbuhan hijau.

Pembentukan kelompok secara heterogen yang terdiri dari 4-5 orang berdasarkan kemampuan akademik dari skor dasar sebelum dilakukan tindakan. Menurut Trianto (2007:53) siswa dalam kelas terlebih dahulu di rangking, kemudian menentukan tiga kelompok dalam kelas yaitu kelompok atas sebanyak $25 \%$ dari seluruh siswa yang diambil dari siswa rangking, kelompok sedang/tengah $50 \%$ dari seluruh siswa yang diambil dari urutan setelah diambil kelompok atas, dan kelompok bawah sebanayak $25 \%$ dari seluruh siswa yaitu terdiri atas siswa setelah diambil kelompok atas dan kelompok sedang.

Tahap Pelaksanaan Pembelajaran, Pelaksanaan pembelajaran dengan materi pokok tumbuhan hijau dilaksanakan 6 kali pertemuan. Setiap selesai dua kali pertemuan diadakan ulangan harian yang bertujuan untuk melihat perkembangan siswa. Dengan kegiatan sebagai berikut:

a. Siklus I,_Siklus pertama dilakukan sebanyak 3 kali pertemuan dengan satu kali ulangan harian I.

Pada pertemuan pertama, guru menyuruh siswa duduk pada kelompoknya masing - masing yang telah ditentukan. Pada pertemuan ini kegiatan membahas tentang tumbuhan hijau sesuai dengan RPP.

Guru melakukan apersepsi dengan mengaitkan pelajaran melalui pertanyaan pertanyaan. Guru kemudian memotivasi siswa dan menyampaikan tujuan pembelajaran. Setelah itu peneliti menginformasi teknik pembelajaran yang akan dilakukan siswa di dalam pembelajaran kooperatif tipe STAD. Selanjutnya guru menyampaikan kepada siswa tentang konsep - konsep materi pelajaran dengan menggunakan media. Kemudian peneliti memberikan kesempatan kepada kelompok untuk pemecahan masalahnya.

Selama pembelajaran berlangsung, guru duduk dan mengamati para anggota tim yang bekerja baik di beri pujian. Akhirnya siswa merasa senang dapat berdiskusi secara terbuka. Pada pertemuan pertama ini pembelajaran masih berlangsung kaku karena siswa masih belum bisa 
memahami model pembelajaran kooperatif tipe STAD.

Berlangsungnya proses pembelajaran juga masih banyak kekurangan karena banyak siswa yang belum serius dan belum percaya diri untuk menampilkan hasil kerjanya.

Pada pertemuan kedua guru berpedoman kepada rencana pembelajaran RPP yang sesuai dengan materi pembelajaran. Siswa tanpa diinstruksikan sudah mulai membentuk kelompok masing - masing. Pada pertemuan kedua inii membahas tentang proses pembuatan makanan pada tumbuhan hijau yang berpedoman pada LKS. Kegiatan pembekajaran diawali dengan mereview pelajaran sebelumnya. Setelah terjadi kesepakatan bahwa semuanya tidak mendapatkan suatu kesulitan. Maka pelajaran dapat dilanjutkan pada materi selanjutnya. Pada proses pembelajaran, peneliti tidak henti hentinya memberikan motivasi untuk meningkatkan percaya diri siswa. Peneliti memberikan LKS 2 pada masing - masing kelompok. Di dalam suatu tim peneliti member satu kesempatan untuk memecahkan masalah. Siswa saling memberikan pelajaran satu sama lain. Peneliti menunjuk salah satu kelompok untuk memaparkan hasil kerja kelompok ke depan kelas.

Pada pertemuan kali ini suasana pembelajaran sudah mulai berubah dimana masing - masing anggota kelompok sudah berani mengeluarkan ide - idneya sebagai suatu sanggahan. Pada akhir pertemuan peneliti memberi penghargaan kepada kelompok dengan nilai terbaik.

Pada pertemuan ketiga ini guru mengadakan ulanagan harian satu. Materi yang diujikan adalah tumbuhan hijau, proses pembuatan makanan pada tumbuhan hijau. Soal ulangan yang disediakan berbentuk essay. Pelaksanaan ulangan harian satu berlangsung selama 30 menit. Semua siswa mengerjakan dengan serius. Peneliti meminta siswa mengumpulkan lembar jawaban dengan teratur. Diakhir pertemuan soal yang dianggap sulit.

Pada pelaksanaan siklus I yang di dalamnya terdapat pertemuan satu sampai kedua peneliti berkesimpulan bahwa masih ada siswa yang tidak percaya diri dan cendrung tertutup dalam menyajikan dan menerima hasil diskusi di depan kelas. Suasana di dalam kelas juga masih kurang kondusif, dimana ada beberapa siswa yang masih melakukan aktivitas seperti bermain dan tertawa - tawa.

Pada pertemuan keempat pembelajaran membahas tentang tempat penyimpanan cadangan makanan pada tumbuhan. Sama seperti pertemuan sebelumnya, guru membagi kelompok secara acak. Kelompok baru ini diubah kembali berdasarkan hasil perkembangan ulangan harian satu. Hal ini bertujuan untuk member suasana baru kepada siswa dengan teman baru yang diperolehnya.

Peneliti membahas kembali penugasan di rumah. Peneliti memberi motivasi untuk meningkatkan hasil pembelajarn siswa. Peneliti mengamati pada pertemuan keempat ini sudah terjadi kerja sama yang cukup bagus dan bertanggung jawab dalam satu tim. Dimana mereka sudah lebih sabar dalam menjelaskan jawaban dan menerima jawaban kawan lainnya saat mempersentasekan hasil kerja di depan kelas. Peneliti tidak lupa memberi penghargaan kepada tim yang memperoleh nilai terbaik.

Tujuan pembelajaran tercapai dibimbing oleh langkah - langkah pembelajaran yang tersusun secara sistematis.

Pada pertemuan kelima materi pembelajaran memasuki pembahasan manfaat tumbuhan hijau. Guru memotivasi dan menyampaikan tujuan pembelajaran. Selanjutnya peneliti membagikan LKS pada tiap - tiap kelompok. Peneliti meminta semua anggota kelompok untuk berperan aktif dalam memahami dan menguasai hasil kerja kelompok.

Peneliti menunjuk kelompok secara bergiliran untuk menyampaikan dan menyajikan hasil kerja kelompoknya. Pada pertemuan kelima ini, siswa sudah aktif dan sangat bersemangat mengerjakan LKS empat dan memperoleh hasil yang baik.

Pada pertemuan keenam peneliti mengadakan ulangan harian dua dimana mencakup materi tempat penyimpanan cadangan makanan pada tumbuhan, manfaat tumbuhan hijau. Peneliti membagikan soal berbentuk essay pada 32 siswa. Dalam waktu 30 menit, setelah ulangan harian selesai, peneliti menanyakan pendapat siswa mengenai cara pembelajaran yang dilakukan. Siswa berpendapat pembelajaran beberapa pertemuan ini sangatlah menyenangkan. 
Pada siklus II proses pembelajaran pada pertemuan empat dan lima. Aktivitas siswa dan guru jauh lebih meningkat dari siklus I. dimana siswa siswa mengerti langkah - langkah pembelajaran. Oleh karena itu, keseriusan siswa meningkat baik individu maupun kelompok.

Analisis Aktivitas Guru dan Siswa, Pertemuan pertama masih terlihat bahwa pusat pembelajaran adalah guru. Dimana guru masih sangat dominan dalam suatu proses pembelajaran. Guru kurang maksimal dalam pengaturan waktu, sehingga ada langkah langkah pembelajaran kooperatif tipe STAD tidak tersentuh dengan baik.

Pertemuan kedua bercermin pada pertemuan pertama, guru sudah lebih hati - hati dalam mengolah waktu pembelajaran sehingga langkah - langkah pembelajaran kooperatif tipe STAD, sehingga penyampaian materi bisa sampai ke siswa.

Pada pertemuan keempat guru sudah mulai menguasai langkah - langkah pembelajaran kooperatif sehingga pengaturan waktu tidak sia - sia. Dalam setiap sesi pembelajaran.

Pertemuan kelima guru sudah sangat terampil dan terencana dalam proses pembelajaran tahapan kooperatif tipe STAD.

Pada tabel di atas pada pertemuan 1,2, 4, dan 5 aktivitas guru mengalami peningkatan. Aktivitas guru pada pertemuan 1 masih kurang baik. Sedangkan pertemuan 1 dan 2 aktivitas guru menunjukkan perubahan walaupun sedikit. Pada pertemuan 2, 4, 5 guru sudah lebih mahir dalam menerapkan pembelajaran kooperatif tipe STAD. Guru dapat menyimpulkan dan menanggapi persoalan - persoalan siswa untuk menguatakan materi yang diberikan.

Pertemuan pertama aktivitas siswa terdapat banyak kekurangan. Hal ini dikarenakan siswa belum dapat memahami proses pembelajaran kooperatif tipe STAD. Suasana kelas masih tampak gaduh, interaksi tidak terarah antara kelompok satu dengan kelompok lainnya.

Pertemuan kedua siswa masih belum semuanya berani mengungkapkan ide - ide dalam diskusi kelompok. Tapi, kepercayaan diri siswa mulai meningkat, hal ini dapat kita lihat pada sudah sangat antusias dalam memberi tanggapan. Pada pertemuan ketiga, masih ada beberapa siswa yang belum menyelesaikan UH 1 dengan baik. Pertemuan keempat sudah tampak sekali peningkatan tanpa melalui instruksi dari guru mereka sudah melakukan tugas kelompok dengan penuh tanggungjawab. Guru hanya bertindak sebagai fasilitator saja.

Pada pertemuan kelima aktivitas pembelajarn siswa amat baik, karena kepahaman mereka meningkat maka tugas - tugas dapat dilaksanakan dengan baik. Dan mereka cendrung lebih berani dalam mengemukakan pendapat. Pada pertemuan keenam saat dilangsungkan $\mathrm{UH}$ 2 secara umum siswa sudah dapat mengerjakan soal latihan nyaris sempurna. Hanya tiga atau empat orang yang masih di bawah KKM.

Hal tersebut dapat dilihat adanya peningkatan kredibilitas siswa di setiap pertemuan.

Nilai yang diperoleh dari masing masing siswa diakumulasikan kepada kelompok, kemudian untuk mendapatkan kriteria penghargaan kelompok dicarilah nilai rata - rata. Data penghargaan masing - masing kelompok siklus 1 dan 2 disajikan

hasil pengamatan yang tertuang pada tabel tersebut menunjukkan bahwa siklus 1 terdapat 4 hebat dan 3 super, serta 1 baik. Sedangkan pada siklus 2 terdapat 2 hebat dan 6 super. Pada siklus 1 skor nilai ulangan harian yang didapat dari guru meningkat, sehingga setiap anggota kelompok dapat menyumbangkan hasil yang maksimal sehingga dapat menyumbang skor tertinggi untuk kelompoknya.

Pada siklus 2, terdapat peningkatan penghargaan kelompok. Penghargaan kelompok sangat berperan dalam memotivasi siswa agar terus memperbaiki diri dan belajar lebih aktif.

Dari hasil pengamatan siklus II, masih adanya siswa kesulitan menerapkan pembelajaran kooperatif tipe STAD. Karena guru harus membimbing siswa dan memerlukan waktu lama untuk mengarahkan siswa di kelompok.

Dari hasil siklus 2 dengan pembiasaan pembelajaran kooperatif tipe STAD, siswa sudah dapat peningkatan hasil belajar dan tujuan pembelajaran sudah dapat dicapai.

Dari data siklus 1 dan 2, pembelajaran tipe STAD telah mengalami peningkatan dalam beberapa hal, misalnya dalam peningkatan ketuntasan belajar siswa hasil UH 1 ke UH 2 ada peningkatan. Peningakatan penghargaan kelompok, peningkatan kelompok dapat 
meningkatkan semangat siswa dalam belajar sehingga pada pembelajaran STAD siswa termotivasi untuk mendapatkan penghargaan dan upaya selalu aktif dalam belajar. Peningkatan aktivitas siswa, dilihat dari rata - rata pada siklus 1 dan 2 ada peningkatan. Di siklus 1 kategori baik, dan di siklus 2 menjadi amat baik. Dapat diambil kesimpulan bahwa setiap pertemuan aktivitas siswa semakin baik, karena siswa telah memahami tipe STAD ini. Dan adanya

\section{KESIMPULAN DAN SARAN}

Berdasarkan hasil penelitian, dapat diambil kesimpulan, bahwa penerapan model pembelajaran kooperatif tipe STAD mampu meningkatkan hasil belajar ipa kelas V SDN 06 Perawang Barat

Berdasarkan kesimpulan dari penelitian, dapat dikemukakan saran - saran sebagai berikut: 1) Untuk menerapkan pembelajaran dengan menggunakan metode pembelajaran peningkatan aktivitas guru, selama proses pembelajaran berlangsung ada peningkatan disetiap pertemuan. Pada penelitian ini guru dan siswa sangat berperan dalam meningkatkan siswa.

Dengan demikian hasil analisis tindakan ini mendukung hipotesis yang diajukan bahwa jika model pembelajaran kooperatif tipe STAD diterapkan, maka dapat meningkatkan hasil belajar ipa kelas V SDN 06 Perawang Barat.

\section{DAFTAR PUSTAKA}

Arikunto, Suharsimi. 1998. Dasar-dasar Evaluasi Pendidikan. Jakarta : Bumi Aksara.

Departemen Pendidikan dan Kebudayaan. 1999. Kamus Besar Bahasa Indonesia. Jakarta: Balai Pustaka. kooperatif tipe STAD, sebaiknya guru membuat perencanaan pembelajaran yang sistematis sehingga pembelajaran dapat terjadi sesuai dengan rencana, sehingga tidak ada waktu yang terbuang sia - sia. 2) Bahasan ipa yang dikembangkan dalam penelitian ini dapat dikembangkan lagi pada materi lainnya.
Dimyati dan Mudjiono. 1999. Belajar dan Pembelajaran. Jakarta: Rineka Cipta.

Nana Sudjana. 1995. Penilaian Hasil Proses Belajar Mengajar. Bandung: PT. Remaja Rosda Karya. 